\title{
Heat shock-induced apoptosis in germ line cells of Triatoma infestans Klug
}

\author{
Maria Luiza S. Mello ${ }^{l}$, Sílvya S. Marial and Maria Cristina H. Tavares ${ }^{1,2}$
}

\begin{abstract}
The survival of Triatoma infestans and of somatic cells from this species is affected by heat shock. In this study, we examined the cell death responses of male germ line cells from 5 th instar nymphs 7 and 30 days after heat shock exposure $\left(40^{\circ} \mathrm{C}, 1 \mathrm{~h}\right)$. The preparations were stained by the Feulgen reaction and the TUNEL immunocytochemical assay. Apoptosis was elicited by heat shock, with positive TUNEL responses in spermatogonial chromatin and chromosomes, spermatids and sperm cells. Spermatogonia were most affected seven days after the shock whereas some spermatids and sperm cells exhibited DNA fragmentation only thirty days after heat shock. The rate of cell death varied among the cells. In some cases, cellular differentiation was unaffected by heat shock, with DNA fragmentation occurring towards the end of spermatogenesis.
\end{abstract}

\section{INTRODUCTION}

The incidence of survival and molting and the nuclear phenotypic characteristics of the Malpighian tubules of Triatoma infestans, a blood-sucking insect and vector of Chagas' disease, are affected by several stress-inducing agents, including heat and cold shocks (Álvares-Garcia, 1988; Rodrigues et al., 1991; Dantas and Mello, 1992; Mello et al., 1995; Tavares, 1998). Changes in the nuclear phenotype of Malpighian tubule epithelial cells are related to cell survival or apoptosis/necrosis (Dantas and Mello, 1992; Mello et al., 1995; Tavares, 1998).

Although there is spontaneous death of germ line cells, especially spermatogonia, during normal spermatogenesis in rats (Roosen-Runge, 1973; Huckins, 1978; Allan et al., 1992), morphological images typical of apoptosis during spermatogenesis in T. infestans have been reported only after gamma-ray irradiation and exposure to heavy metals (Âlvares-Garcia, 1988; Mello et al., 1995). Since these cell death responses were elicited by stressed conditions, heat shocks may also induce apoptosis in germ line cells of $T$. infestans. In this study we used the Feulgen reaction and the TUNEL immunocytochemical assay to examine the effect of heat shock $\left(40^{\circ} \mathrm{C}\right.$ for $\left.1 \mathrm{~h}\right)$ on the germ line cells of $T$. infestans testis.

\section{MATERIAL AND METHODS}

Fifth instar nymphs of T. infestans Klug (Hemiptera, Reduviidae) were used. Organs from at least three specimens were processed under control and treated conditions. The control specimens were maintained at $28^{\circ} \mathrm{C}$ and $80 \%$ relative humidity, conditions traditionally used to rear this species in the laboratory at SUCEN (Mogi-Guaçu, SP) since 1980. The treated specimens were exposed to heat shock $\left(40^{\circ} \mathrm{C}, 1 \mathrm{~h}\right)$ and examined 7 days and 30 days later. The insects were fed on hen blood once a week.

Testes were squashed in a drop of absolute ethanolacetic acid, 3:1 (v/v). After removal of the coverslip, the preparations were immersed in $70 \%$ ethanol for $5 \mathrm{~min}$ and air-dried. One testis of the pair was stained by the Feulgen reaction following hydrolysis in $4 \mathrm{M} \mathrm{HCl}$ at $25^{\circ} \mathrm{C}$ for 65 min, while the other was used in the TdT-mediated dUTPbiotin nick end labeling (TUNEL) method (in situ cell death detection kit, Boehringer Mannheim, FRG) as described by the manufacturer. Endogenous peroxidase activity was blocked with $3 \% \mathrm{H}_{2} \mathrm{O}_{2}$ in absolute methanol for $30 \mathrm{~min}$ at room temperature. Negative controls were performed by omitting TdT. V79 fibroblasts were used as a positive control for apoptosis (Maria et al., 2000).

\section{RESULTS AND DISCUSSION}

Apoptotic nuclei and vesicles were evident in preparations treated with the Feulgen reaction especially seven days after the heat shock (Figure 1a-c). The appearance of these structures resembled those reported after gammaray irradiation and heavy metal treatment in this species (Álvares-Garcia, 1988; Mello et al., 1995). DNA fragmentation in the spermatogonial chromatin and chromosomes and in spermatids and sperm cells was seen only with the TUNEL assay (Figures 1e-g, 2a-c). V79 cells showed the expected positive response in the TUNEL assay (Maria et al., 2000) (Figure 1d). No reactions were observed in preparations incubated without TdT.

The TUNEL positive response was scarcely located in the spermatogonia of insects kept at $28^{\circ} \mathrm{C}$ (control) (Figure 1e), but increased significantly seven days after the heat shock (Figure 1f), and then decreased thereafter (Figure $1 \mathrm{~g}$ ). Only in specimens studied 30 days after heat shock 


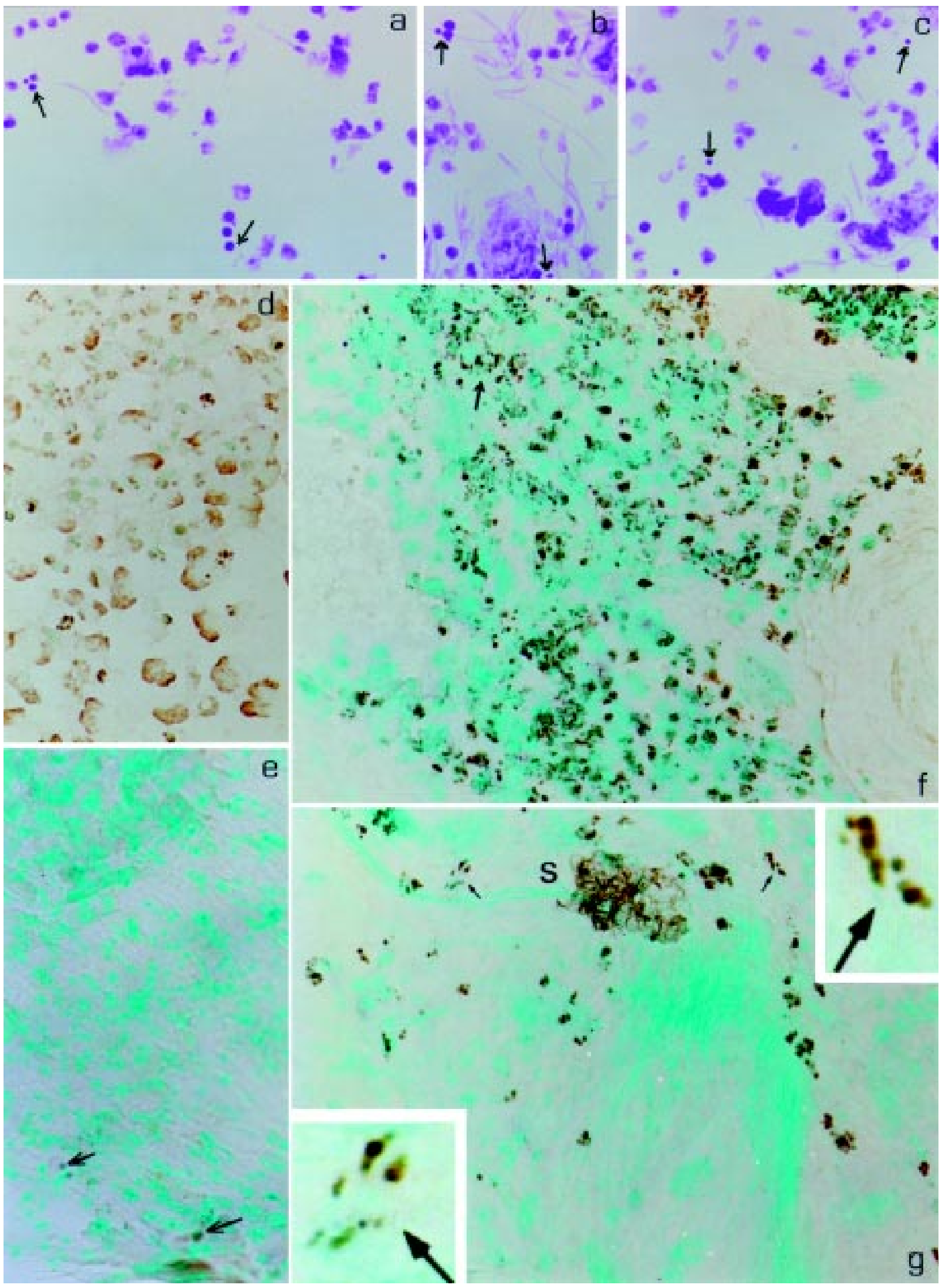

Figure 1 - Male germ line cells of T. infestans $7(\mathbf{a}, \mathbf{b}, \mathbf{f})$ and $30(\mathbf{c}, \mathbf{g})$ days after exposure of the insects to short-duration heat shock. a-c, Feulgen staining; d-g, TUNEL assay; d, control V79 cells showing a positive TUNEL response; e, control specimen not exposed to heat shock. The arrows show apoptotic nuclei/vesicles (panels a-c) and a positive TUNEL response (panels e-g). Details of the reaction in chromosomes are shown in the insets of panel g. 400X; insets, 2000X. 

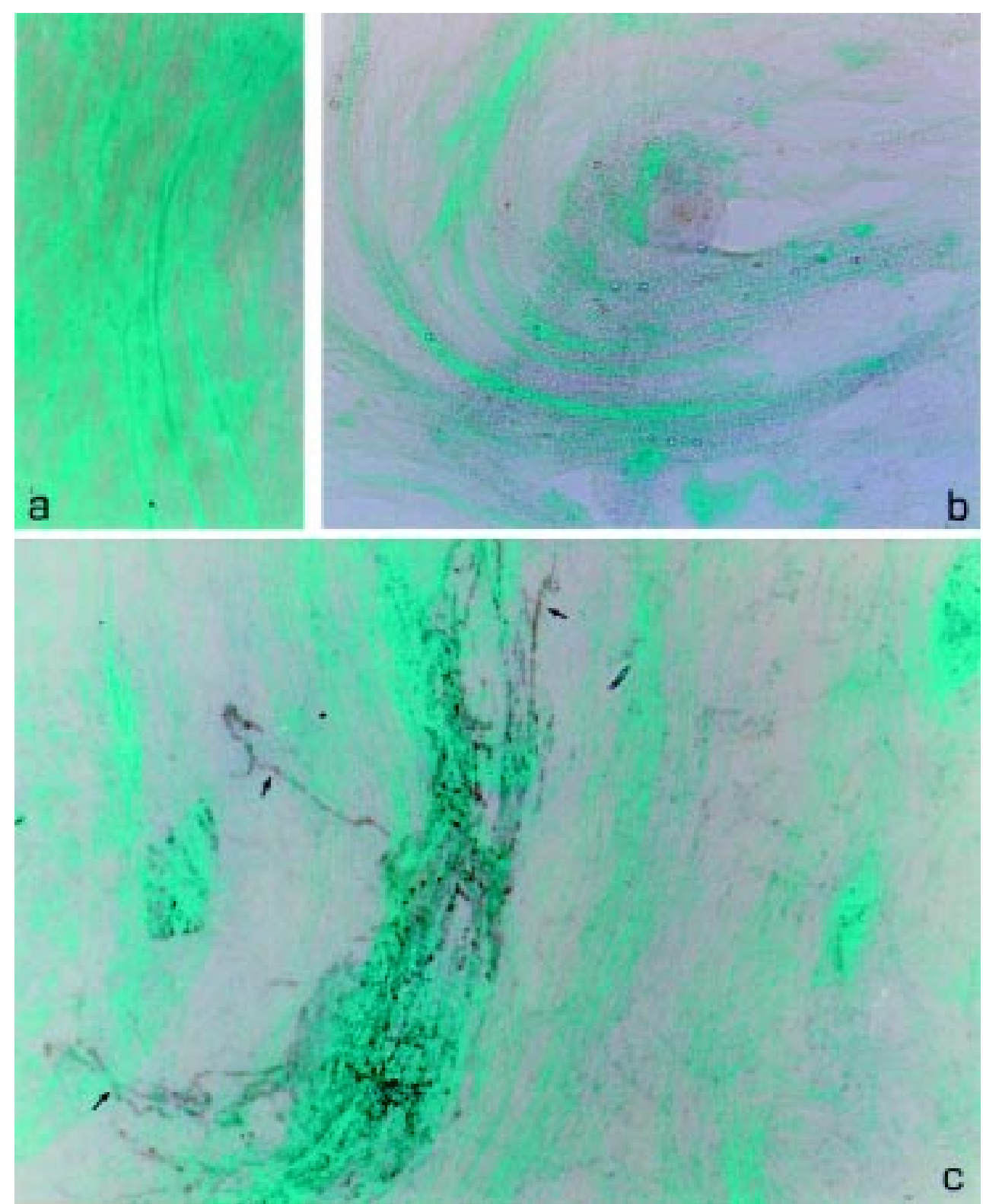

Figure 2 - Sperm cells of T. infestans 7 (b) and 30 (c) days after exposure of the insect to short-duration heat shock. a, Control. The arrows in $\mathbf{c}$ indicate DNA fragmentation revealed by the TUNEL assay. 1000X.

was the TUNEL positive response observed in part of the elongated spermatids and in individual spermatozoa (Figures $1 \mathrm{~g}$, $2 \mathrm{a}-\mathrm{c})$. These results demonstrate that heat shock $\left(40^{\circ} \mathrm{C}, 1\right.$ h) elicits apoptosis in sperm line cells of T. infestans, although the rate of death apparently varies among the cells.

In some cells, cell differentiation progressed normally after heat shock, and DNA fragmentation occurred only at the end of spermatogenesis.

\section{ACKNOWLEDGMENTS}

The present study is dedicated to Prof. Benedicto de Campos Vidal on the occasion of his seventieth birthday. The authors thank Dr. Vera L.C.C. Rodrigues (SUCEN, Mogi-Guaçu) for providing the insects, Dr. Stephen Hynslop (UNICAMP) for revising the manuscript and the Brazilian National Council for Research and Development (CNPq) and the São Paulo State Research Foundation (FAPESP, grant 99/02547-8) for financial support. Publication supported by FAPESP.

\section{RESUMO}

Uma vez que em Triatoma infestans a sobrevivência de células somáticas e dos próprios espécimes é afetada por choques de temperatura, foi estudada a indução de morte celular em células da linhagem germinativa masculina de ninfas de 5 o. estadio 7 e 30 dias após choque de $1 \mathrm{~h} \mathrm{a} 40^{\circ} \mathrm{C}$. Os preparados foram submetidos 
à reação de Feulgen e ao teste imunocitoquímico TUNEL. Foi encontrada apoptose induzida pelo choque de temperatura, sendo que respostas positivas ao TUNEL foram vistas na cromatina e em cromossomos de espermatogônias e em espermátides e espermatozóides. As espermatogônias foram afetadas principalmente 7 dias após o choque, enquanto algumas espermátides e espermatozóides exibiram fragmentação de DNA apenas 30 dias após o choque. Admite-se que a velocidade com a qual avança o processo de morte celular varie nessas células. Diferenciação celular não é impedida em parte das células afetadas, permitindo que a fragmentação de seu DNA ocorra mais tardiamente, inclusive no fim da espermatogênese.

\section{REFERENCES}

Allan, D.J., Harmon, B.V. and Roberts, S.A. (1992). Spermatogonial apoptosis has three morphologically recognizable phases and shows no circadian rhythm during normal spermatogenesis in the rat. Cell Prolif. 25: 241-250.

Álvares-Garcia, R.S. (1988). Efeitos da radiação gama sobre os fenótipos nucleares de alguns tipos celulares de Triatoma infestans Klug (Hemiptera, Reduviidae), Master's thesis, UNICAMP, Campinas, SP.

Dantas, M.M. and Mello, M.L.S. (1992). Changes in the nuclear pheno- types of Triatoma infestans Klug, induced by thermal shocks. Rev. Bras. Genet. 15: 509-519.

Huckins, C. (1978). The morphology and kinetics of spermatogonial degeneration in normal adult rats: an analysis using a simplified classification of germinal epithelium. Anat. Rec. 190: 905-926.

Kerr, J.B. (1992). Spontaneous degeneration of germ cells in normal rat testis: assessment of cell types and frequency during the spermatogenic cycle. J. Reprod. Fertil. 95: 825-830.

Maria, S.S., Vidal, B.C. and Mello, M.L.S. (2000). Image analysis of DNA fragmentation and loss in V79 cells under apoptosis. Genet. Mol. Biol. 23: $109-112$

Mello, M.L.S., Tavares, M.C.H., Dantas, M.M., Rodrigues V.L.C.C., Garcia, N.L. and Maria, S.S. (2000). Death and survival cell strategies following heat shock in Malpighian tubules of Triatoma infestans. Journal - (in press).

Rodrigues, V.L.C.C., Mello, M.L.S., Ferraz Filho, A.N. and Dantas, M.M. (1991). Sobrevivência e ocorrência de muda em Triatoma infestans Klug (Hemiptera, Reduviidae) após choque de temperatura. Rev. Saúde Pública 25: 461-467.

Roosen-Runge, E.C. (1973). Germinal cell loss in normal metazoan spermatogenesis. J. Reprod. Fertil. 35: 331-348.

Tavares, M.C.H. (1998). Apoptose após choque hipertérmico em Triatoma infestans Klug (Hemiptera, Reduviidae). MSc thesis, UNICAMP, Campinas.

(Received March 8, 2000) 